\title{
GSK-3 $\beta$ and MMP-9 Cooperate in the Control of Dendritic Spine Morphology
}

\author{
Ilona Kondratiuk ${ }^{1} \cdot$ Szymon Lęski $^{2} \cdot$ Małgorzata Urbańska $^{3} \cdot$ Przemyslaw Biecek $^{4}$. \\ Herman Devijver $^{5}$ • Benoit Lechat ${ }^{5}$ - Fred Van Leuven ${ }^{5}$ - Leszek Kaczmarek ${ }^{1}$. \\ Tomasz Jaworski ${ }^{1}$
}

Received: 26 October 2015 / Accepted: 8 December 2015 /Published online: 6 January 2016

(C) The Author(s) 2016. This article is published with open access at Springerlink.com

\begin{abstract}
Changes in the morphology of dendritic spines are prominent during learning and in different neurological and neuropsychiatric diseases, including those in which glycogen synthase kinase- $3 \beta$ (GSK-3 $\beta$ ) has been implicated. Despite much evidence of the involvement of GSK-3 $\beta$ in functional synaptic plasticity, it is unclear how GSK-3 $\beta$ controls structural synaptic plasticity (i.e., the number and shape of dendritic spines). In the present study, we used two mouse models overexpressing and lacking GSK-3 $\beta$ in neurons to investigate how GSK-3 $\beta$ affects the structural plasticity of dendritic spines. Following visualization of dendritic spines with DiI dye, we found that increasing GSK-3 $\beta$ activity increased the number of thin spines, whereas lacking GSK-3 $\beta$ increased the number of stubby spines in the
\end{abstract}

Leszek Kaczmarek

1.kaczmarek@nencki.gov.pl

Tomasz Jaworski

t.jaworski@nencki.gov.pl

1 Laboratory of Neurobiology, The Nencki Institute of Experimental Biology, 3 Pasteur, 02-093 Warsaw, Poland

2 Laboratory of Neuroinformatics, The Nencki Institute of Experimental Biology, Warsaw, Poland

3 Laboratory of Molecular and Cellular Neurobiology, The International Institute of Molecular and Cell Biology, Warsaw, Poland

4 Faculty of Mathematics, Informatics, and Mechanics, University of Warsaw, Warsaw, Poland

5 Department of Human Genetics, Experimental Genetics Group LEGTEGG, KULeuven, Leuven, Belgium dentate gyrus. Under conditions of neuronal excitation, increasing GSK-3 $\beta$ activity caused higher activity of extracellularly acting matrix metalloproteinase-9 (MMP9), and MMP inhibition normalized thin spines in GSK$3 \beta$ overexpressing mice. Administration of the nonspecific GSK-3 $\beta$ inhibitor lithium in animals with active MMP-9 and animals lacking MMP-9 revealed that GSK-3 $\beta$ and MMP-9 act in concert to control dendritic spine morphology. Altogether, our data demonstrate that the dysregulation of GSK- $3 \beta$ activity has dramatic consequences on dendritic spine morphology, implicating MMP-9 as a mediator of GSK- $3 \beta$-induced synaptic alterations.

Keywords GSK-3 $\beta$ - MMP-9 · Imaging · Transgenic mice · Dendritic spines $\cdot$ Synaptic plasticity

\section{Introduction}

Dendritic spines comprise the postsynaptic compartments of excitatory inputs as the basic units of information processing and storage [1]. Dynamic changes in dendritic spine morphology, the growth of new spines, and the elimination of existing spines can occur on very different time scales, reflecting adjustments of the synaptic strength that supports learning and memory [2]. The regulation of dendritic spine morphology is governed by the extracellular matrix (ECM), cell adhesion molecules (CAMs), and the cytoskeleton that is controlled by specific signaling networks [3]. Components of the ECM, including matrix metalloproteinases (MMPs), have been proposed to actively contribute to dendritic spine remodeling. Accumulating evidence suggests a specific role for MMP-9 in regulating the structural plasticity of dendritic spines [4]. 
Glycogen synthase kinase-3 (GSK-3) is a serine/ threonine protein kinase that besides glycogen metabolism also regulates many critical cellular processes in most organs, including the central nervous system [5]. GSK-3 exists as two isozymes, GSK- $3 \alpha$ and GSK-3 $\beta$, that have similar structures but are not functionally identical in neurons [6]. GSK-3 $\beta$ is the more essential isozyme, because its genetic deletion is lethal in mouse embryogenesis, in contrast to GSK-3 $\alpha$ [7-11]. GSK-3 $\beta$ is ubiquitously present in the brain, including neurons and synaptosomes [12] that essentially represent excitatory synapses [13]. At excitatory synapses, GSK-3 $\beta$ balances two major forms of synaptic plasticity: longterm potentiation (LTP) and long-term depression (LTD), which are both $N$-methyl-D-aspartate (NMDA) receptor-dependent [14]. During LTP, NMDA receptor activation inhibits GSK-3 $\beta$ activity through phosphorylation at Ser9 via the PI3K/Akt pathway, whereas during LTD, GSK-3 $\beta$ activity increases [14]. This apparent duality in molecular mechanisms that require the modulation of GSK-3 $\beta$ phosphorylation at Ser9 during experimental LTP or LTD is crucial for learning and memory $[12,14,15]$.

The dysregulation of signaling pathways that involve GSK-3 is associated with the pathogenesis of several neurological and psychiatric disorders, including mental retardation, schizophrenia, depression, and Alzheimer's disease [16]. These disorders are also characterized by aberrant structural changes in dendritic spines.

Mouse models that lack or overexpress either of the GSK-3 isozymes mimic various pathological conditions that are observed in different neuropsychiatric and neurological disorders [17]. Balancing GSK-3 activity in mice by genetic or pharmacological manipulations can rescue some of the functional defects in behavior and synaptic transmission [12, 18-20]. Consequently, the pharmacological inhibition of GSK-3 was proposed as an attractive therapeutic strategy for mental illnesses. Psychoactive drugs (e.g., lithium salts) that are used to treat bipolar disorder, depression, and schizophrenia inhibit GSK-3, among other enzymes [21].

Despite growing evidence of the role of GSK-3 in functional synaptic plasticity $[11,12,14,15,22-26]$, it is far from clear how GSK-3 $\beta$ controls structural synaptic plasticity, reflected by alterations in the number and shape of dendritic spines [27-29]. In the present study, we analyzed mice either overexpressing or lacking GSK-3 $\beta$ in neurons to clarify the relationship between aberrant GSK-3 activity and the structural plasticity of dendritic spines. We identified GSK-3 $\beta$ as a critical regulator of dendritic spine architecture. Unexpectedly, we also discovered that MMP-9, the extracellular MMP, acts as a downstream regulator of GSK- $3 \beta$-induced dendritic spine alterations.

\section{Materials and Methods}

\section{Animals}

\section{GSK-3 $\beta$ Transgenic and Knockout Mice}

GSK-3 $\beta$ transgenic (TG; GSK-3 $\beta[$ S9A]) mice overexpress the constitutively active form of GSK-3 $\beta$, with a mutation of Ser9 to alanine, specifically in neurons under the control of the mouse Thy-1 gene promoter. Heterozygous GSK$3 \beta[\mathrm{S} 9 \mathrm{~A}]$ mice were maintained on an FVB/N genetic background $[30,31]$. GSK-3 $\beta[\mathrm{S} 9 \mathrm{~A}]$ mice were compared with wild-type (WT) littermates as controls.

Neuron-specific GSK-3 $\beta$-deficient (GSK- $3 \beta^{\mathrm{n}-/-}$ ) mice were obtained by crossing mice with floxed GSK- $3 \beta$ genes with Thy-1-Cre recombinase transgenic mice. GSK- $3 \beta^{\mathrm{n}-/-}$ mice were maintained on a mixed FVB-C57BL/6 genetic background [9]. GSK-3 $\beta^{\mathrm{n}-/-}$ mice were compared with GSK- $3 \beta^{\text {loxP/loxP }}$ littermates, which lack Cre recombinase, as controls. For both genotypes, the Thyl-gene promoter has been shown to yield postnatal expression of the respective transgene in central neurons only $[9,11,30,31]$.

\section{MMP-9 Transgenic and Knockout Animals}

Transgenic Wistar rats overexpress autoactivating MMP-9 under the control of the synapsin 1 promoter (MMP-9 TG rats) [32]. MMP-9 homozygous knockout mice (MMP-9 KO mice) were obtained from Dr. Z. Werb (University of California, San Francisco) [33] and maintained on a C57B1/6 background.

All of the animal experiments were performed by certified researchers in accordance with regional, national, and European regulations concerning animal welfare and animal experimentation. The researchers were authorized and supervised by the University Animal Welfare Commission (Ethische Commissie Dierenwelzijn, KULeuven, Leuven, Belgium) and the Ethical Committee on Animal Research of the Nencki Institute (Warsaw, Poland).

\section{Lithium Chloride Treatment}

MMP-9 TG rats and MMP-9 KO mice were subjected to a regimen of 4 weeks of lithium salt treatment [34]. The experimental animals were divided into four groups ( $n=3 /$ group): WT animals that were fed a control diet (WT); KO and TG animals that were fed a control diet (MMP-9 KO, MMP-9 TG); WT animals that were fed a lithium salt-supplemented diet $(\mathrm{WT}+\mathrm{Li})$; and $\mathrm{KO}$ and TG animals that were fed a lithium salt-supplemented diet (MMP-9 KO + Li, MMP-9 $\mathrm{TG}+\mathrm{Li})$. Lithium chloride $(0.2 \%[w / w])$ was supplemented in custom-prepared food pellets (Vivari, Warsaw, Poland). Treatment commenced at 3 months of age, and the diets were provided ad libitum for 1 month. Animals that fed the lithium 
salt-supplemented diet were given drinking water with $1.5 \%$ $(w / v)$ sodium chloride to counteract the peripheral side effects of lithium ions.

\section{Dendritic Spine Analysis}

Dendritic spine analysis was performed essentially as described previously [35]. GSK-3 $\beta$ [S9A] and GSK- $3 \beta^{\mathrm{n}-1-}$ mice and $\mathrm{Li}^{+}$-treated MMP-9 KO mice and MMP-9 TG rats and their respective controls were anesthetized with pentobarbital and transcardially perfused first with phosphate-buffered saline (PBS) and then with $1.5 \%$ paraformaldehyde (PFA) at room temperature. The brains were postfixed in $1.5 \%$ PFA for $20 \mathrm{~min}$ and transferred to ice-cold PBS for another $20 \mathrm{~min}$. The brains were cut into $130-\mu \mathrm{m}$-thick slices using a vibratome and left in PBS for $1 \mathrm{~h}$. The sections were labeled by gene gun delivery of tungsten particles (Bio-Rad, Hercules, CA, USA) coated with the lipophilic dye 1,1'-dioctadecyl-3,3, 3',3'-tetramethylindocarbocyanine perchlorate (DiI; D-3911, Thermo Fisher). The slices were subsequently incubated in $1.5 \%$ PFA for $24 \mathrm{~h}$ to allow the dye to diffuse into neuronal processes, including spines. Confocal images of secondary apical dendrites of the dentate gyrus field were acquired under 561-nm fluorescent illumination. Spines were measured and analyzed using semiautomatic custom software (SpineMagick) [36].

\section{Dendritic Spine Clustering}

The virtual skeletons of dendritic spines were obtained in SpineMagick. Spine length was calculated as the length of the path from the spine top to the dendrite along the virtual skeleton of the spine. To analyze the shapes of spines, the virtual skeleton of each spine from an individual image was transformed to form a straight line. The images were then rescaled to normalize the spine area. For each spine diameter, we defined width as a function of distance from the dendrite, denoted d(h).

We classified 9429 spines according to shape from GSK$3 \beta$-modified mice and their respective controls using a twostep procedure [37]. First, all $9429 \mathrm{~d}(\mathrm{~h})$ functions were clustered into 36 clusters. Second, the clusters were manually sorted into three groups (i.e., mushroom, stubby, and thin spines) based on visual inspection of clustered spines. The data analysis was performed using custom scripts that were written in Python using NumPy and SciPy $[38,39]$ and Matplotlib [40].

\section{Pentylenetetrazole Treatment}

To induce seizures and activate MMP-9, the mice were injected with the $\gamma$-aminobutyric acid-A $\left(\mathrm{GABA}_{\mathrm{A}}\right)$ receptor antagonist pentylenetetrazole (PTZ) [41]. GSK-3 $\beta[S 9 A]$ $(n=6)$ and WT $(n=6)$ mice (3.5-4 months old) were habituated to handling by subjecting them to intraperitoneal (i.p.) injections of $0.9 \% \mathrm{NaCl}$ twice per day for 7 days before PTZ stimulation. On day 8 , WT and GSK-3 $\beta[$ S9A] mice were divided into groups that received either PTZ (50 mg/kg, i.p.) or saline $(0.9 \% \mathrm{NaCl}$, i.p.). The mice were sacrificed by cervical dislocation 10 min after the onset of PTZ-induced seizures or after saline injection. This 10-min time point was chosen based on a timeline of MMP-9 activity upon PTZ treatment $(50 \mathrm{mg} / \mathrm{kg}$ ) in WT mice. The mice were sacrificed 0,5 , and $10 \mathrm{~min}$ after PTZ-induced seizure onset ( $n=3 /$ time point).

\section{Acute Hippocampal Slices and GM 6001 Treatment}

GSK- $3 \beta[\mathrm{S} 9 \mathrm{~A}]$ and WT mice ( $n=5$ /group) were anesthetized with isoflurane and decapitated. The brains were quickly removed and placed in cold NMDG solution (135 $\mathrm{mM} \mathrm{N}$-methyl-D-glutamine, $1 \mathrm{mM} \mathrm{KCl}, 1.2 \mathrm{mM} \mathrm{KH}{ }_{2} \mathrm{PO}_{4}, 1.5 \mathrm{mM}$ $\mathrm{MgCl}_{2}, 0.5 \mathrm{mM} \mathrm{CaCl}, 20 \mathrm{mM}$ choline bicarbonate, and $10 \mathrm{mM}$ D-glucose, $\mathrm{pH}$ 7.4) saturated with a carbogen gas mixture $\left(95 \% \mathrm{O}_{2}\right.$ and $\left.5 \% \mathrm{CO}_{2}\right)$. Both hemispheres were cut into $300-\mu \mathrm{m}$ coronal slices with a vibratome. The slices were left for recovery in artificial cerebrospinal fluid (aCSF; $119 \mathrm{mM} \mathrm{NaCl}, 2.5 \mathrm{mM} \mathrm{KCl}, 26.2 \mathrm{mM} \mathrm{NaHCO}, 1 \mathrm{mM}$ $\mathrm{NaH}_{2} \mathrm{PO}_{4}, 2.5 \mathrm{mM} \mathrm{CaCl}_{2}, 1.3 \mathrm{mM} \mathrm{MgCl}$, and $10 \mathrm{mM}$ Dglucose) and saturated with carbogen at room temperature for $1 \mathrm{~h}$. Slices from WT and GSK-3 $\beta[\mathrm{S} 9 \mathrm{~A}]$ mice were then transferred to aCSF that contained either $0.004 \%$ dimethylsulfoxide (DMSO) or GM6001 (1 $\mu \mathrm{M}$ in DMSO) and incubated at room temperature for $1 \mathrm{~h}$. Following fixation with $1.5 \%$ PFA for $20 \mathrm{~min}$, the slices were processed for DiI dendrite labeling and spine analysis.

\section{Western Blotting}

Protein extracts were subjected to sodium dodecyl sulfatepolyacrylamide gel electrophoresis (SDS-PAGE; $8 \%$ gels) and electrotransferred (semi-dry transfer) to polyvinylidene difluoride membranes (Immobilon-P, Millipore). The membranes were blocked with $10 \%(w / v)$ dried nonfat milk powder in Tris-buffered saline with $0.1 \%$ Tween- 20 and incubated with the following primary antibodies: rabbit anti-pGSK-3 $\alpha /$ $\beta$ (Ser21/9) (1:1000 dilution; \#9331, Cell Signaling Technology); rabbit anti-GSK-3 $\alpha / \beta$ (1:1000 dilution; \#5676P, Cell Signaling Technology); rabbit anti-pAktS473 (1:1000 dilution; \#4060, Cell Signaling Technology), rabbit antipAktT308 (1:1000 dilution; \#4056, Cell Signaling Technology); rabbit total Akt (1:1000 dilution; \#9272, Cell Signaling Technology); mouse anti- $\beta$-dystroglycan ( $\beta$-DG; 1:500 dilution; NCL-b-DG, Novocastra); and mouse antiglyceraldehyde-3-phosphate dehydrogenase (GAPDH; 1:2000 dilution; MAB374, Chemicon). Following washing with TBST, the membranes were incubated with horseradish 
peroxidase-labeled secondary antibody (anti-mouse or antirabbit; Vector Laboratories). After washing, peroxidase activity was visualized with ECL plus reagent (GE Healthcare). Signal densities were analyzed using GeneTools software (SynGene, England).

\section{Matrix Metalloproteinase Gel Zymography}

The extraction of MMP from mouse brain tissue was performed as described previously [42]. Following cervical dislocation, the brains were rapidly removed. The cerebral cortex was isolated, homogenized, and centrifuged. Proteins from the supernatant were precipitated with cold ethanol, and the precipitate was solubilized in sample buffer. The pellets from the first centrifugation (Triton X-100-insoluble) were resuspended, incubated at $60^{\circ} \mathrm{C}$, and centrifuged. The proteins from the resulting supernatant were precipitated and solubilized in nonreducing sample buffer.

Triton X-100-insoluble samples were subjected to SDSPAGE on $8 \%$ gels that contained $2 \mathrm{mg} / \mathrm{ml}$ gelatin (SigmaAldrich). Following protein separation, the gels were washed with $2.5 \%$ Triton X-100 and incubated with moderate shaking in developing buffer for the enzymatic reaction. The gels were stained with $0.1 \%$ Coomassie Blue G-250.

\section{Dissociated Hippocampal Cultures}

Dissociated hippocampal cultures were prepared from newborn (postnatal day 0) Wistar rats [35]. The brains were removed, and hippocampi were isolated on ice in dissociation medium. The hippocampi were then dissociated with papain and rinsed in dissociation medium and MEM plating medium. The hippocampi were triturated in plating medium, and cells were diluted in OptiMEM (Thermo Fisher) and centrifuged. The cells were plated at a density of 120,000 cells per poly-Llysine-coated coverslip (Sigma). The cells were kept in maintenance medium at $37{ }^{\circ} \mathrm{C}$ under a humidified $5 \% \mathrm{CO}_{2}$ atm. All of the experiments were performed on days 17-19 in vitro.

\section{Cell Stimulation}

Hippocampal neurons were incubated for $5 \mathrm{~min}$ with $400 \mathrm{ng} / \mathrm{ml}$ of recombinant MMP-9 or inactive MMP-9 E402A mutant or with MMP-9 and wortmannin (100 nM in DMSO) in maintenance medium. The final concentration of DMSO did not exceed $0.016 \%$. After stimulation, the cells were washed with maintenance medium, lysed with reducing SDS sample buffer, and subjected to Western blotting.

\section{Statistical Analysis}

Graphs were prepared using Prism 5.01 software (GraphPad, San Diego, CA, USA). Spine densities were compared using the Mann-Whitney test. The numbers of differently shaped spines were compared using the $\chi^{2}$ test. The effects of lithium and the MMP-9 inhibitor crossed with the effects of GSK-3 $\beta$ modification in mice on dendritic spine morphology were statistically analyzed using nested Gaussian mixed models. Animals and photographs were considered nested random effects, whereas the inhibitor and genetic modification were considered crossed fixed effects. To stabilize variance, the length-to-width ratio was log-transformed. Modeling was performed using the R statistical package [43] with lme4 [44] (available on CRAN) and DendriticSpineR (available on GitHub). Graphs presenting densitometric quantification of WB were prepared in Excel and results were compared using Student $t$ test.

\section{Results}

\section{Mice Expressing Constitutively Active GSK-3 $\beta$ had Longer and Thinner Dendritic Spines, Whereas GSK-3 $\beta$-Deficient Mice had Shorter Dendritic Spines}

We studied how GSK3 $\beta$ affects structural synaptic plasticity in the adult central nervous system in mice either overexpressing constitutively active GSK-3 $\beta$ in neurons (GSK-3 $\beta[\mathrm{S} 9 \mathrm{~A}]$ ) or deficient in GSK-3 $\beta$ specifically in neurons (GSK-3 $\beta^{\mathrm{n}-/-}$ ). We compared spine density and morphology with control WT mice and mice with a floxed GSK-3 $\beta$ gene (GSK-3 $\beta^{\text {loxP/loxP }}$ ), respectively. The morphometric analysis of spines in neurons that were stained with the DiI dye was performed in the dentate gyrus (Fig. 1a) using the length-to-width ratio as the most reliable reflection of spine morphology [35].

GSK-3 $\beta[$ S9A] mice had similar spine densities (Fig. 1b) but significantly longer spines, with a $60 \%$ larger average length-to-width ratio than WT mice (Fig. 1c). Conversely, GSK- $3 \beta^{\mathrm{n}-1-}$ mice had a $14 \%$ smaller length-to-width ratio of dendritic spines compared with GSK-3 $\beta^{\text {loxP/loxP }}$ mice (Fig. 1c). Spine density was reduced by $28 \%$ in neurons in GSK-3 $\beta^{\mathrm{n}-/-}$ mice (Fig. 1b). Importantly, the two control strains (WT and GSK-3 $\beta^{\text {loxP/loxP }}$ ) did not differ with regard to the length-to-width ratio (Fig. 1c), although spine density in GSK- $3 \beta^{\text {loxP/loxP }}$ mice was $14 \%$ higher than in WT mice (Fig. 1b).

To further understand how GSK-3 $\beta$ affects dendritic spine shape, we clustered spines into mushroom, stubby, and thin categories (Fig. 1d). GSK-3 $\beta[$ S9A] mice exhibited a significant increase in the population of thin spines ( $28 \%$ more) and a significant decrease in the population of stubby spines ( $21 \%$ less) compared with WT mice, whereas GSK $-3 \beta^{\mathrm{n}-/-}$ mice exhibited an increase in the population of stubby spines (13\% more) compared with GSK-3 $\beta^{\text {loxP/loxP }}$ mice. 
Fig. 1 GSK- $3 \beta$ imbalance in neurons alters dendritic spine density and morphology. a Example photographs of DiIstained secondary apical dendrites of granule neurons in the dentate gyrus in GSK-3 $\beta[\mathrm{S} 9 \mathrm{~A}]$ and GSK- $3 \beta^{\mathrm{n}-/-}$ mice. Scale bar $=$ $2 \mu \mathrm{m}$. b Spine densities of dentate gyrus neurons in GSK-3 $\beta$ [S9A] and GSK-3 $\beta^{\mathrm{n}-/-}$ mice. The data are expressed as mean \pm SEM. *** $p<0.001$ (Mann-Whitney test). c Cumulative histogram of dendritic spine length-to-width ratio in GSK- $3 \beta^{\mathrm{n}-1-}$ and GSK$3 \beta$ [S9A] mice $(p<0.001$, vs. GSK-3 $\beta^{\text {loxP/loxP }}$ and WT; nested analysis of variance). $\mathbf{d}$ Spine morphology in GSK-3 $\beta$ [S9A] and GSK- $3 \beta^{\mathrm{n}-/-}$ mice. $* * * p<0.001$ ( $\chi^{2}$ test). GSK$3 \beta[\mathrm{S} 9 \mathrm{~A}]: n=6$; WT: $n=6$; GSK$3 \beta^{\mathrm{n}-/-}: n=4$; GSK-3 $\beta^{\text {loxP/loxP }}$ : $n=5$ mice) a
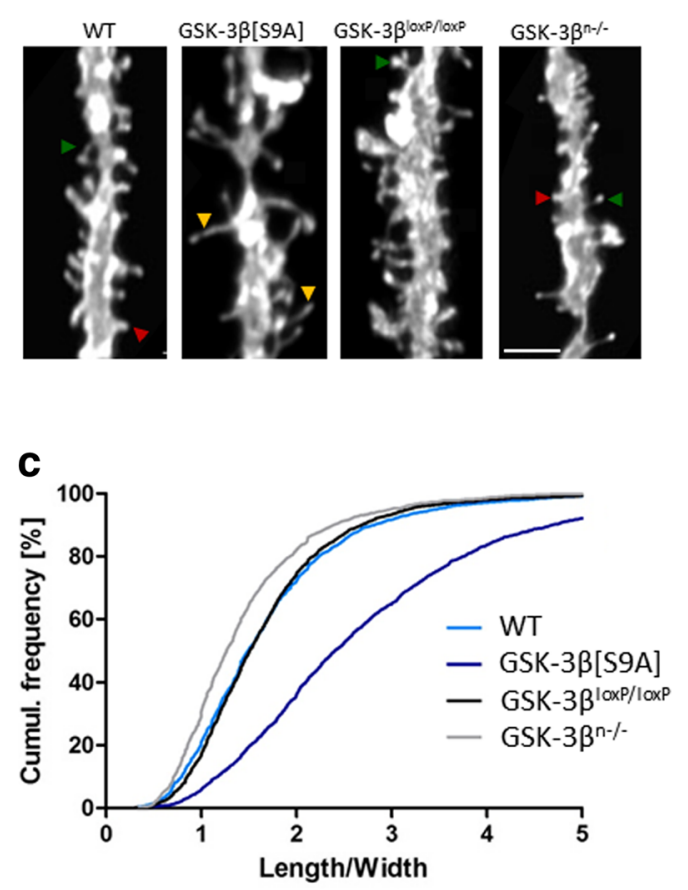

b
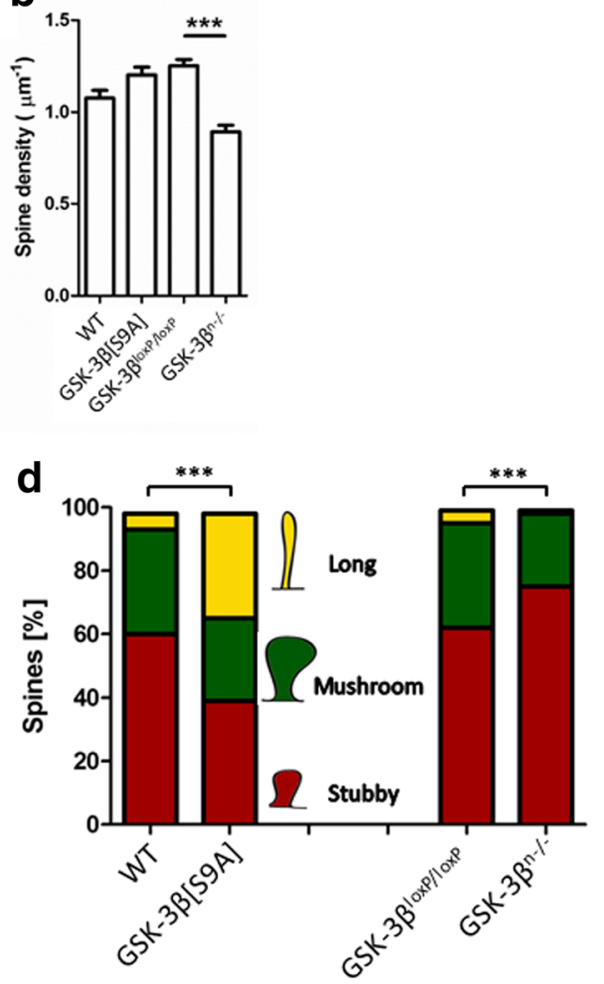

\section{GSK-3 $\beta$ Regulation of Dendritic Spine Morphology Involved MMP-9}

The elongated phenotype of dendritic spines in GSK-3 $\beta$ [S9A ] mice was reminiscent of a similar observation in MMP-9overexpressing TG rats [35]. MMP-9 is an extracellularly acting protease that regulates dendritic spine shape $[35,45,46]$. Consequently, we hypothesized that GSK- $3 \beta$ regulates MMP-9 activity to control dendritic spine morphology. We further hypothesized that this co-regulation would be dysfunctional in the absence of GSK-3 $\beta$ (i.e., in GSK- $3 \beta^{\mathrm{n}-/-}$ mice).

To test these hypotheses, we analyzed MMP-9 activity in GSK-3 $\beta[$ S9A $]$ and GSK- $3 \beta^{\text {n- }--}$ mice (Fig. 2a). Because MMP-9 is released by synaptic stimulation, we habituated mice for 7 days to exclude any possible effects of the handling procedure. On day 8 , the mice were injected with saline (basal condition) or PTZ to produce strong neuronal excitation. Previous studies reported that PTZ-induced MMP-9 activity in vivo, and the sensitivity to PTZ-induced epileptogenesis was MMP-9-dependent [32, 41]. Gelatin gel zymography demonstrated that MMP-9 activity was unaffected by GSK-3 $\beta$ [S9A] overexpression in the basal condition, whereas GSK-3 $\beta[\mathrm{S} 9 \mathrm{~A}]$ potentiated MMP-9 activity almost twofold upon neuronal excitation (Fig. 2b).

Interestingly, these experiments showed that GSK $-3 \beta^{\mathrm{n}-/-}$ mice were extremely susceptible to PTZ-induced seizures. On average, $50 \%$ died within $3 \mathrm{~min}$ after the injection of $50 \mathrm{mg} / \mathrm{kg}$ PTZ. Lower PTZ doses $(35 \mathrm{mg} / \mathrm{kg})$ extended the survival of
GSK- $3 \beta^{\mathrm{n}-/-}$ mice to $10 \mathrm{~min}$, but at this lower dose neither GSK- $3 \beta^{\text {loxP/loxP }}$ nor GSK- $3 \beta^{\text {n-/- }}$ mice developed seizures, with no changes in MMP-9 activity (data not shown). Consequently, the assessment of MMP-9 activity was not relevant in GSK- $3 \beta^{\mathrm{n}-/-}$ mice.

We then sought to determine whether MMP-9 mediates GSK-3 $\beta$-induced changes in dendritic spine morphology. We analyzed acute hippocampal slices from GSK-3 $\beta$ [S9A] mice, both without MMP inhibition and after MMP inhibition, and measured spines of granular neurons in the dentate gyrus (visualized by DiI dye; Fig. 2c). The length-to-width ratio was significantly higher (by $12 \%$ ) in GSK-3 $\beta[\mathrm{S} 9 \mathrm{~A}]$ slices compared with WT slices, confirming the in vivo results (Figs. 1c, $2 \mathrm{~d})$. Interestingly, the application of GM6001 to GSK$3 \beta[\mathrm{S} 9 \mathrm{~A}]$ slices significantly reduced the length-to-width ratio by $10 \%$ (Fig. 2d). These results indicate that increases in MMP-9 activity contribute to the elongation of dendritic spines under conditions of increased GSK-3 $\beta$ activity.

\section{Longer and Thinner Dendritic Spines Produced by Activated MMP-9 Were Normalized by Lithium Chloride}

To further investigate the effects of the relationship between MMP-9 and GSK-3 $\beta$ activity on the morphology of dendritic spines, we chronically inhibited GSK-3 in MMP-9 KO mice and MMP-9 TG rats. We used lithium because: (i) GSK-3 is inhibited by lithium ions in vivo [47-50], (ii) different and 
a
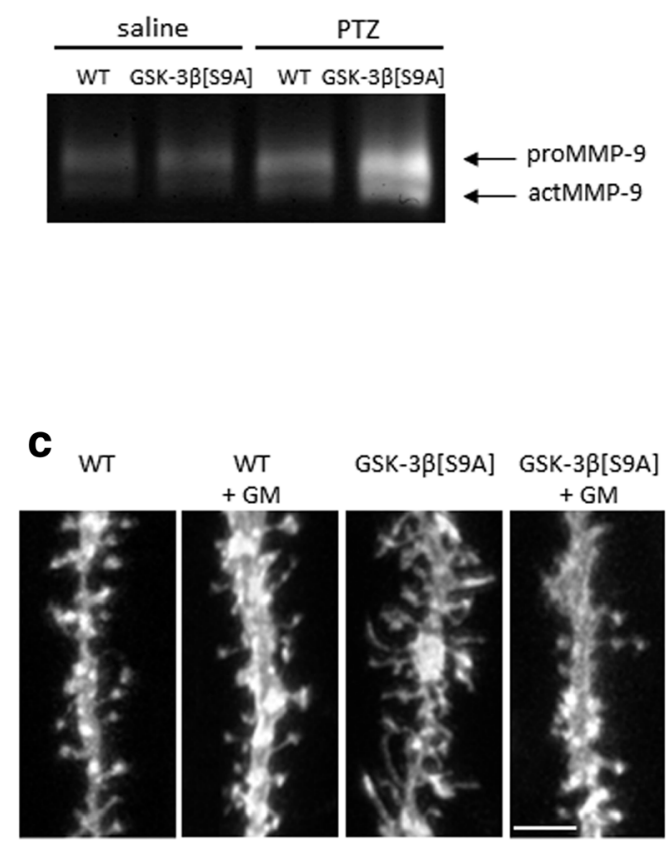

Fig. 2 GSK-3 $\beta$ regulates dendritic spine morphology in an MMP-9dependent manner. a WT and GSK-3 $\beta[\mathrm{S} 9 \mathrm{~A}]$ mice were stimulated with saline or PTZ, and MMP-9 activity in hippocampal homogenates was analyzed by gelatin gel zymography. b MMP-9 activity in control and GSK-3 $\beta[\mathrm{S} 9 \mathrm{~A}]$ mice. The data are expressed as mean \pm SEM. $* * p<0.01$ (Mann-Whitney test). c Example photographs of DiI-stained apical dendrites of dentate gyrus neurons in acute hippocampal slices from

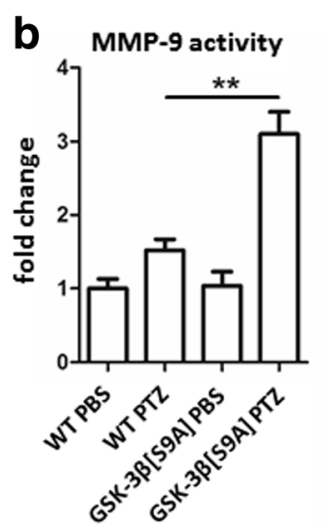

d

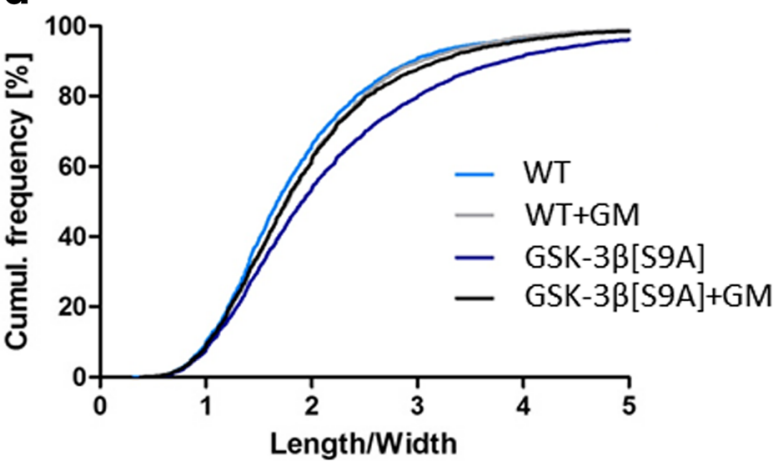

WT and GSK-3 $\beta[$ S9A] mice after administration of the MMP-9 inhibitor GM6001. Scale bar $=2 \mu \mathrm{m}$. d Cumulative histogram of spine length-to-width ratio in WT and GSK-3 $\beta[\mathrm{S} 9 \mathrm{~A}]$ mice $(p<0.01$; nested analysis of variance). GM6001 normalized the dendritic spine lengthto-width ratio in GSK-3 $\beta[\mathrm{S} 9 \mathrm{~A}]$ mice $(p<0.01$; nested analysis of variance). WT: $n=5$; WT-GM6001: $n=5$; GSK-3 $\beta[\mathrm{S} 9 \mathrm{~A}]: n=5$; GSK$3 \beta[\mathrm{S} 9 \mathrm{~A}]-\mathrm{GM} 6001: n=5$ mice more specific GSK-3 inhibitors mimic the behavioral actions of lithium salt [51, 52], (iii) the deletion of GSK- $3 \alpha$ or GSK$3 \beta$ mimics the behavioral actions of lithium salt in mice [48, 53, 54], (iv) lithium salt-sensitive behavior is reversed by increasing brain GSK-3 activity [18], and (v) impairments in synaptic transmission caused by increased GSK-3 $\beta$ activity are normalized by lithium salt [12]. Animals were treated with lithium chloride for 30 days, and spines of neurons in the dentate gyrus were visualized using DiI dye (Fig. 3a, b ). MMP-9 KO mice had a significantly smaller (by $11 \%$ ) spine length-to-width ratio compared with WT mice (Fig. 3c ). MMP-9 TG rats had a significantly larger (by $8 \%$ ) lengthto-width ratio compared with WT rats (Fig. 3d). Chronic lithium chloride treatment significantly reduced the spine lengthto-width ratio in WT mice (Fig. 3c) and WT rats (Fig. 3d) by 13 and $18 \%$, respectively, producing a similar dendritic spine phenotype as neuronal GSK-3 $\beta$ deficiency (Figs. $1 \mathrm{c}$, $d$ and $3 \mathrm{c}$, d).

If MMP-9 and GSK-3 $\beta$ regulate dendritic spine morphology through distinct molecular mechanisms, then the absence of MMP-9 activity should not affect the observed effects of GSK-3 on spine alterations. We observed no changes in the length-to-width ratio in MMP$9 \mathrm{KO}$ mice that were treated with lithium chloride compared with untreated MMP-9 KO mice (Fig. 3c). In contrast, lithium chloride treatment reduced (by $14 \%$ ) the length-to-width ratio in MMP-9 TG rats (Fig. 3d). These results demonstrate that GSK-3 and MMP-9 act in concert on the same signaling pathway(s) to control dendritic spine morphology.

\section{MMP-9 Induced GSK-3 $\beta$ Phosphorylation Through the PI3K/Akt Signaling Pathway}

Higher GSK-3 $\beta$ activity concomitantly increased MMP-9 activity upon neuronal excitation. Therefore, we investigated whether secreted MMP-9 affects neuronal signaling. We analyzed MMP-9 activity in WT mice, in which MMP-9 was activated by an injection of PTZ (Fig. 4a). PTZ significantly increased MMP-9 activity, which coincided with increases in 
a

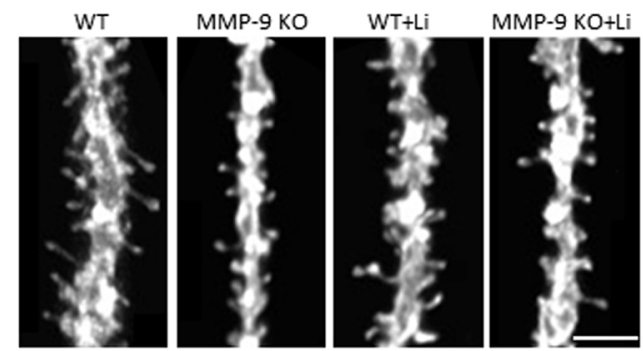

C

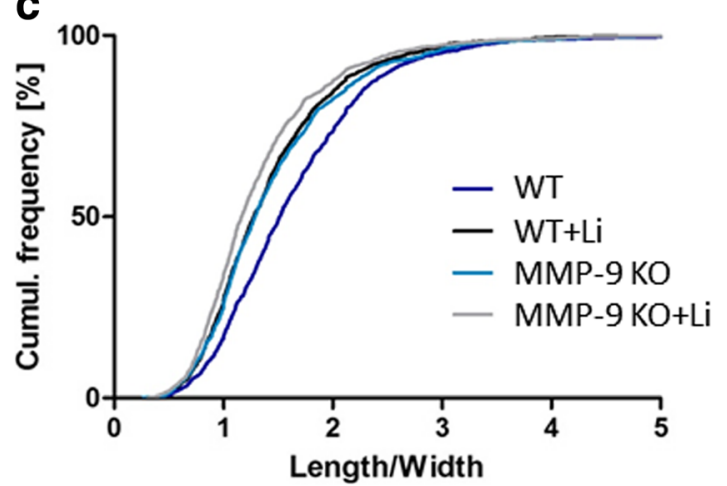

Fig. 3 Dendritic spine morphology in MMP-9 KO mice and MMP-9 TG rats after chronic GSK-3 inhibition. a Example photographs of DiIstained apical dendrites of dentate gyrus granule neurons in WT and KO MMP-9 mice treated with lithium chloride. b Example photographs of Dil-stained apical dendrites of dentate gyrus granule neurons in WT and TG MMP-9 rats treated with lithium chloride. Scale bar $=2 \mu \mathrm{m}$. c Cumulative histogram of dendritic spine length-to-width ratio in WT and KO MMP-9 mice treated with lithium. MMP-9 KO mice had shorter dendritic spines $(p<0.05$; nested analysis of variance). Lithium significantly reduced the length-to-width ratio of dendritic spines in WT

the levels of the cleaved $30-\mathrm{kDa}$ form of $\beta$-DG, the neuronal substrate of MMP-9 (Fig. 4a, b) [41]. We also observed an increase in the levels of inhibitory GSK-3 $\beta$ phosphorylation at Ser9 that followed the increase in MMP-9 activity (Fig. 4a, b).

To confirm that MMP-9 regulated GSK-3 $\beta$ activity, we incubated dissociated hippocampal cultures with recombinant MMP-9 or its inactive mutant MMP-9 E402A as a control. Active MMP-9, but not the inactive mutant MMP-9 E402A, increased the levels of the cleaved $\beta$-DG and of phosphorylated GSK-3 $\beta$ at Ser9 and phosphorylated Akt at Ser473 (Figs. $4 \mathrm{c}, \mathrm{d}$ and $5 \mathrm{a}, \mathrm{b}$ ). Among the factors that regulate GSK-3 $\beta$, the PI3K/Akt pathway is by far the major signal transducer. Treatment with the PI3K inhibitor wortmannin prevented exogenous MMP-9-induced GSK-3 $\beta$ phosphorylation (Fig. 4c, d), demonstrating that extracellular MMP-9 induced signaling to GSK-3 $\beta$. Surprisingly, wortmannin alone increased levels of $30-\mathrm{kDa}$ form of $\beta$-DG (Fig. 4c, d). Wortmannin, however, did not affect exogenous MMP-9induced $\beta$-DG cleavage (Fig. 4c, d). b

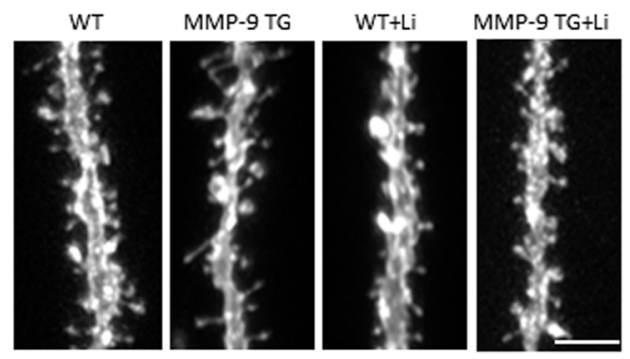

d

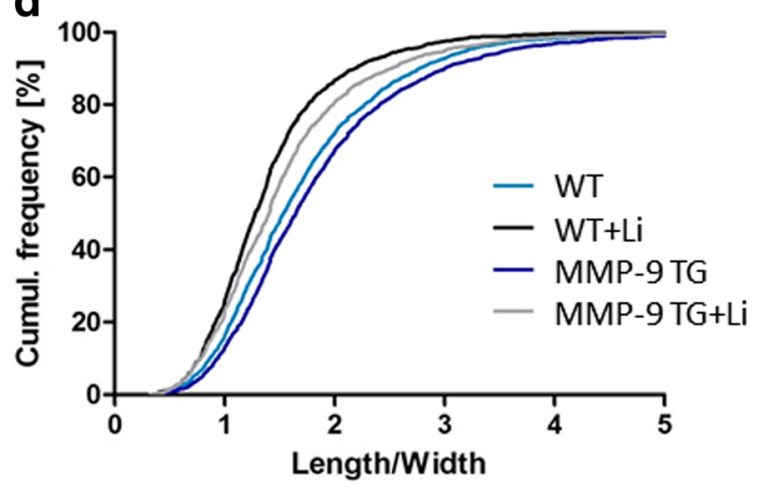

mice ( $p<0.05$; nested analysis of variance), with no effect in MMP-9 KO mice ( $p=0.135$; nested analysis of variance). MMP-9 KO: $n=3$; WT: $n=3$; WT-Li: $n=3$; MMP-9 KO-Li: $n=3$ mice. d Cumulative histogram of dendritic spine length-to-width ratio in MMP-9 TG rats. MMP-9 TG rats had a higher length-to-width ratio of dendritic spines $(p<0.05$; nested analysis of variance). Lithium reduced the length-to-width ratio of dendritic spines in WT and MMP-9 TG rats $(p<0.001$; nested analysis of variance). MMP-9 TG: $n=3$; WT: $n=3$; WT-Li: $n=3$; MMP-9 TG-Li: $n=3$ rats

\section{Discussion}

Here, we studied the direct role of the GSK-3 $\beta$ isozyme in dendritic spine morphology that is fundamentally and translationally important and in need of in depth examination. We analyzed dendritic spines in the dentate gyrus because we observed previously that GSK- $3 \beta$ affects the volume of the dentate gyrus and related functional aspects such as speciestypical behavior [55]. Furthermore, this region is essential in the trisynaptic circuit that processes information from the entorhinal cortex to the CA3 region of the hippocampus [56]. In the present study, we found that an imbalance of GSK-3 $\beta$ activity affects the morphology of dendritic spines bidirectionally. Increasing GSK- $3 \beta$ activity resulted in an elongation of spines, shifting the spine population toward the thin type. Conversely, reducing GSK-3 $\beta$ activity either genetically or pharmacologically resulted in a shortening of spines, shifting their population toward the stubby type. These shifts occurred at the expense of the mushroom spine type, suggesting that GSK- $3 \beta$ can actively switch the balance of dendritic 

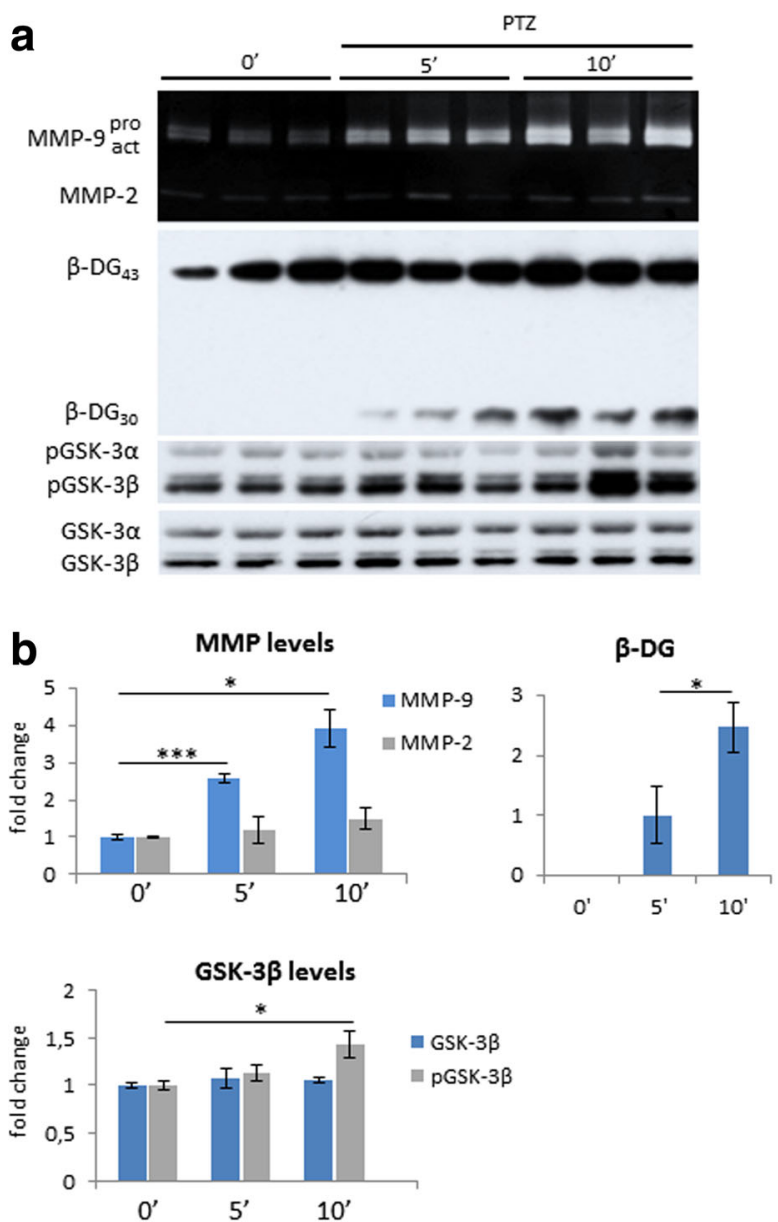

Fig. 4 MMP-9 activity induced GSK-3 $\beta$ phosphorylation via PI3K/Akt signaling pathway. a Neuronal excitation induced MMP-9 activity, followed by GSK-3 phosphorylation, in PTZ-treated WT mice that were analyzed 0,5 , and 10 min after PTZ treatment. MMP-9 activity in total hippocampal homogenates was visualized by gelatin gel zymography (upper panel) and Western blot for $\beta$-DG cleavage (middle panel) and total and phosphorylated GSK3 isozymes (lower panel). b Densitometric quantification of pGSK-3 $\beta$ Ser9, total GSK- $\beta$,

spines toward less mature populations. Likewise, in a different model, GSK- $3 \beta$ deficiency produced similar changes in dendritic spine populations in the CA1 region of the hippocampus [27]. On the other hand, higher neuronal GSK-3 $\beta$ activity decreased postsynaptic density (PSD) in hippocampal granule neurons, indicating less mature spines [28]. Our current results and previous studies demonstrate that GSK- $3 \beta$ activity regulates the morphology of dendritic spines in the dentate gyrus and $\mathrm{CA}$ regions of the hippocampus.

\section{Relation of GSK-3 $\beta$ to Spine Morphology and MMP-9}

MMP-9 is a protease that is secreted at excitatory synapses upon enhanced synaptic activity, allowing it to cleave CAMs and thereby reshape synaptic connections and morphology
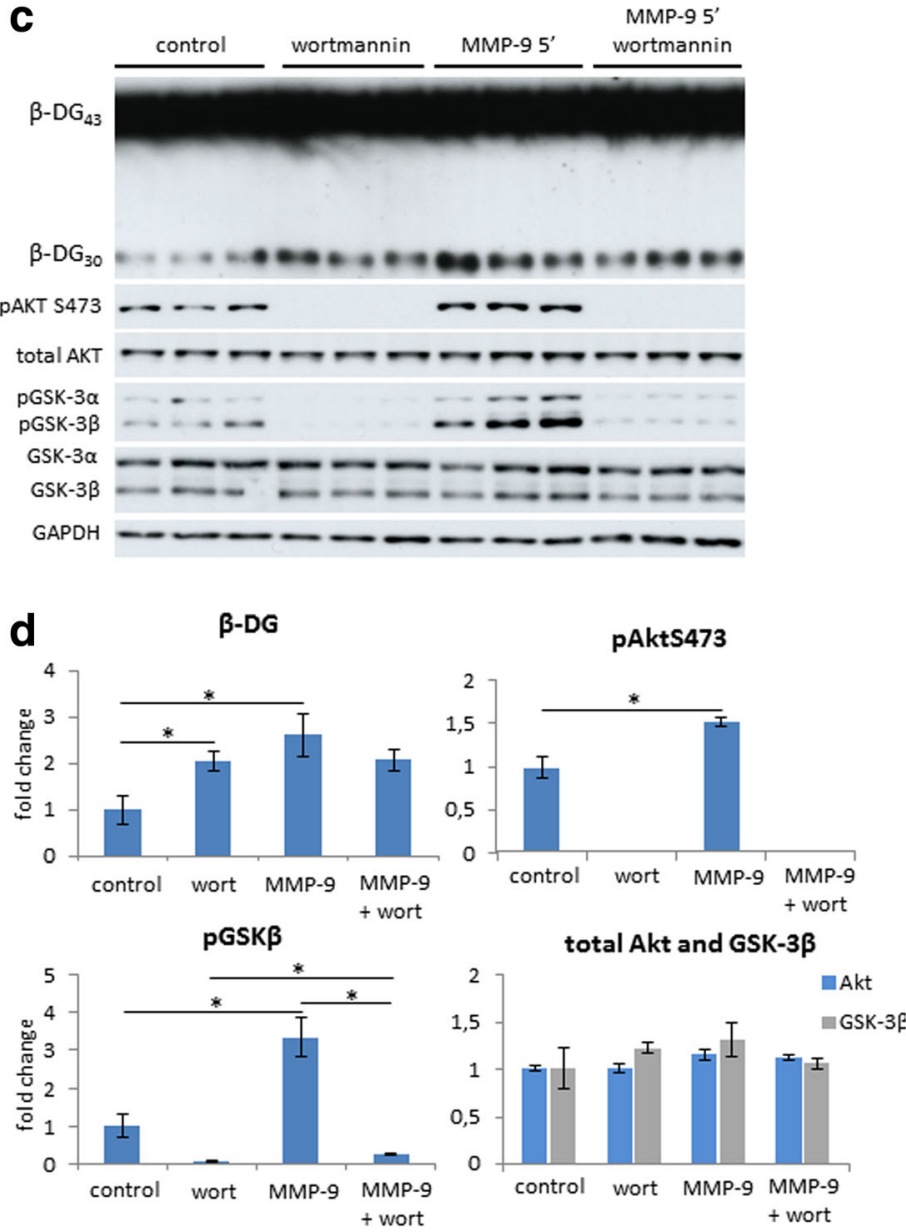

$\beta$-DG and MMP-9 levels. The data are expressed as mean \pm SEM. $* p<0.05$ (Student $t$ test). $n=3$ mice for each condition. c Autoactive MMP-9 induced GSK-3 $\beta$ phosphorylation in hippocampal neuronal cultures. PI3K inhibitor wortmannin prevented MMP-9-induced GSK$3 \beta$ phosphorylation. d Densitometric quantification of $\beta-D G$, pAktSer473, pGSK-3 $\beta$ Ser9, total Akt, and total GSK-3 $\beta$ levels. The data are expressed as mean \pm SEM. $* p<0.05$ (Student $t$ test). $n=3$ culture wells for each condition

[57-59]. Our results suggest that active GSK-3 $\beta$ promotes the secretion of MMP-9 in response to neuronal excitation, and MMP-9 in turn influences intracellular signaling pathways that involve GSK-3 $\beta$. MMP-9 was previously shown to activate extracellular signal-regulated kinase $1 / 2$ and Akt in Schwann cells, regardless of its activity (i.e., by hemopexin domain binding to LRP1 receptor) [60]. Our current results showed that the enzymatic activity of MMP-9 is important for initiating the Akt-GSK-3 cascade in neurons. This is supported by our findings of differential Akt phosphorylation at Ser473 and Thr308 upon application of active and inactive MMP-9 forms. Inactive MMP-9 induced only Thr308 phosphorylation suggesting that Akt was not fully active in this condition. Only upon the sequential phosphorylation of Thr308 and Ser473, Akt achieves full activity [61]. Here, 


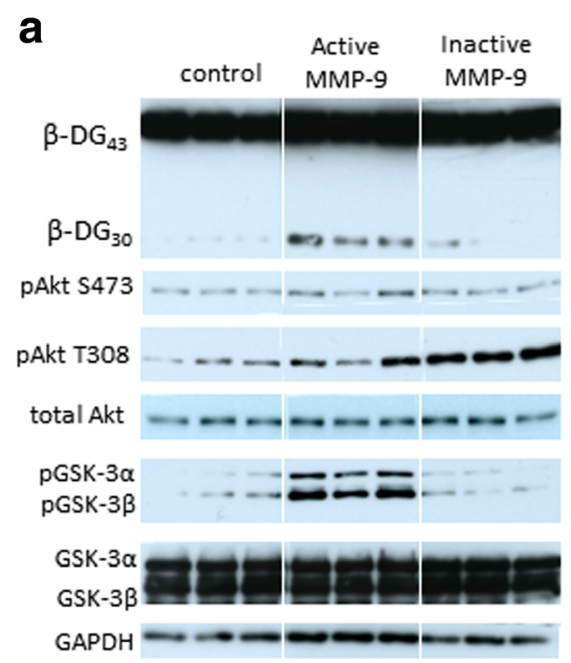

Fig. 5 Active and inactive MMP-9 forms differentially regulate GSK-3 $\beta$ and Akt phosphorylations. a Hippocampal neurons were incubated for $5 \mathrm{~min}$ with $400 \mathrm{ng} / \mathrm{ml}$ of recombinant MMP-9 or inactive MMP-9 E402A
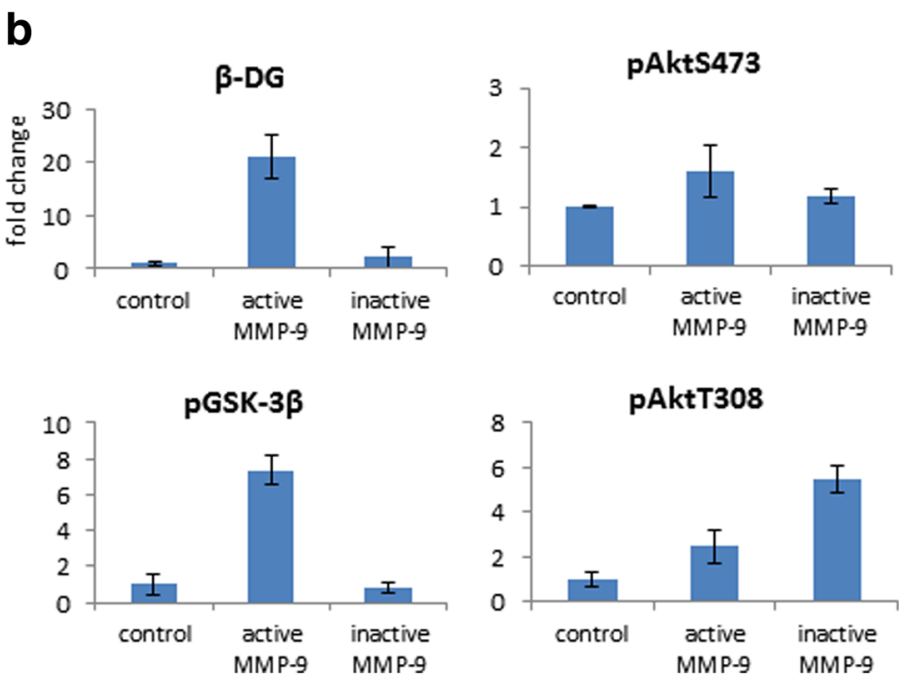

mutant. b Densitometric quantification of $\beta$-DG, pAktSer473, pAktThr308, and pGSK-3 $\beta$ Ser9. The data are expressed as mean \pm SEM. $n=3$ culture wells for each condition
PI3K inhibitor wortmannin efficiently blocked active MMP9-induced Akt and GSK-3 $\beta$ phosphorylations. Interestingly, $\mathrm{p} 110 \delta \mathrm{PI} 3 \mathrm{~K}$ isoform is required for membrane localization of $\beta$-DG [62] which may explain the observed increased $\beta$-DG cleavage by wortmannin. Whether synaptic MMP-9 substrates, such as $\beta$-DG [41] or nectin-3 [63], are involved in signal transduction following application of active MMP-9, remains to be elucidated. Nevertheless, the physiological role for MMP-9 may involve keeping GSK-3 inactive upon neuronal stimulation. In contrast, in brain pathology, GSK-3 overactivation may drive aberrant dendritic spine pathology via activated MMP-9.

Unexpectedly, mice lacking neuronal GSK-3 $\beta$ were hypersensitive to PTZ, and their acute death prevented an analysis of MMP-9 activity upon neuronal excitation. MMP-9 basal activity was not affected in either of the GSK-3 $\beta$-modified mice, possibly because of the low levels of constitutive MMP-9 or because its activity is affected in specific subfields of the hippocampus [41, 42, 64, 65].

Consistent with the increase in the activity of MMP-9 in GSK-3 $\beta[S 9 A]$ mice, the MMP inhibitor normalized dendritic spines in acute brain slices from GSK-3 $\beta$ [S9A] mice. The data show that higher MMP-9 activity in GSK-3 $\beta$ [S9A] mice translates into a structural outcome that is longer and thinner dendritic spines. Because local protein translation occurs on the order of minutes after synaptic activation [66], GSK-3 $\beta$ is proposed to regulate the local synthesis of MMP-9, in line with our observation that the levels of the MMP-9 precursor increased in GSK-3 $\beta[\mathrm{S} 9 \mathrm{~A}]$ mice that were treated with PTZ. Although this and previous studies did not provide evidence of the involvement of GSK-3 in local protein translation, the activities of other proteins that are involved in controlling this process, such as p70-S6K [67], TSC2/mTOR [68], and eIF4E [69], were shown to be regulated by GSK-3 $\beta$.

Our results implicate MMP-9 as an effector of GSK-3 $\beta$ mediated changes in dendritic spines. The effects of the relationship between GSK-3 $\beta$ and MMP-9 on dendritic spines were further evaluated pharmacologically in MMP-9 KO mice and MMP-9 TG rats. Lithium salts inhibit GSK-3, although not specifically, and normalized in MMP-9 TG rats the longer and thinner dendritic spines. That in MMP-9 KO mice the shorter dendritic spines were not affected by lithium salts is explained by the fact that the observed effect was maximal by the MMP-9 deficiency.

\section{Relation of Spine Morphology to Synaptic Transmission in Health and Disease}

The aberrant morphology of dendritic spines on apical dendrites of granule neurons may have important functional consequences, exemplified by GSK-3 $\beta[\mathrm{S} 9 \mathrm{~A}]$ mice that present impairments in synaptic transmission and hippocampusdependent cognitive tasks (i.e., inhibitory avoidance and novel object recognition) [15].

The relation of spine morphology to synaptic transmission and their dynamic regulations in health and disease are inferred, but the underlying mechanisms are not well understood. In general, mushroom spines have a larger PSD with a higher content of glutamate receptors and are more sensitive to glutamate, which is typical for mature synapses. In contrast, thin slender spines are associated with no or a small PSD that contains NMDA receptors but no or only a few $\alpha$-amino-3hydroxy-5-methyl-4-isoxazolepropionic acid (AMPA) receptors. These spines appear to be transitional and ready for 
strengthening and stabilization by the addition of AMPA receptors and an enlarged PSD, or alternatively, to shrink and dismantle, both in response to more or less synaptic inputs. Furthermore, LTP makes spines become larger, whereas LTD causes shrinkage of spines [70]. Because GSK-3 $\beta$ is essential for LTD [14], the shifts to thinner spines in GSK-3 $\beta$ [S9A] mice or to stubby spines in GSK $3 \beta^{\mathrm{n}-/-}$ mice unlikely reflected physiological processes associated with LTD. Rather, these changes reflect pathological spine alterations, as observed in neurological and neuropsychiatric disorders.

Increased numbers of elongated, thin dendritic spines are a feature of fragile X syndrome (FXS), a disorder that is characterized by mental retardation [71]. Conversely, a reduction of the number of dendritic spines is evident in neurodegenerative diseases including Alzheimer's disease, whereas in psychiatric diseases such as schizophrenia and depression alternations in spine morphology in either direction are evident [72].

In FXS, the higher incidence of thin spines is explained by an increase in the activity of MMP-9, which is known to cause the elongation and thinning of dendritic spines [35, 45, 46, 73]. Furthermore, the fragile $X$ mental retardation protein (FMRP) KO mouse model of FXS exhibits increased levels of GSK- $3 \beta$, whereas mice with active GSK- $3 \alpha / \beta$ isozymes share some autism-related features with FMRP KO mice [74]. GSK-3 $\beta$ was previously reported to downregulate FXR1P, a protein that belongs to a small family of RNA binding proteins that also includes FMRP [75]. Because FMRP KO mice have higher MMP-9 levels [76], we hypothesize that longer and thinner dendritic spines in GSK-3 $\beta[\mathrm{S} 9 \mathrm{~A}]$ mice are caused by the dysregulation of MMP-9 activity. Indeed, higher GSK-3 $\beta[$ S9A] activity potentiated MMP-9 but not MMP-2 in the hippocampus in PTZ-treated mice.

Altogether, our results demonstrate that the dysregulation of GSK-3 $\beta$ activity in either direction has dramatic consequences on dendritic spine morphology that are reminiscent of dendritic spine alternations that are observed in different neurological and neuropsychiatric disorders. Furthermore, our results offer new insights into the possible synaptic mechanisms of these disorders and indicate potential levels of therapeutic interventions.

Acknowledgments This work was supported by a National Science Centre grant (2013/09/N/NZ3/01249 - Preludium) to IK and the EU FP7 NeuroGSK3 grant to FVL. IK acknowledges Foundation for Polish Science project MPD/2009/4. MU was supported by a Polish National Science Centre grant (2011/01/N/NZ3/05409). TJ was supported by EU FP7 Project GA No 264173 (Bio-Imagine) and a scholarship for young and outstanding investigators from the Ministry of Science and Higher Education. We sincerely thank Prof. Jacek Jaworski for critically reading the manuscript and his helpful comments.

\section{Compliance with Ethical Standards}

Conflict of Interest The authors declare that they have no competing interests.
Open Access This article is distributed under the terms of the Creative Commons Attribution 4.0 International License (http:// creativecommons.org/licenses/by/4.0/), which permits unrestricted use, distribution, and reproduction in any medium, provided you give appropriate credit to the original author(s) and the source, provide a link to the Creative Commons license, and indicate if changes were made.

\section{References}

1. van Spronsen M, Hoogenraad CC (2010) Synapse pathology in psychiatric and neurologic disease. Curr Neurol Neurosci Rep 10: 207-214

2. Murakoshi H, Yasuda R (2012) Postsynaptic signaling during plasticity of dendritic spines. Trends Neurosci 35:135-143

3. Hotulainen P, Hoogenraad CC (2010) Actin in dendritic spines: connecting dynamics to function. J Cell Biol 189:619-629

4. Stawarski M, Stefaniuk M, Wlodarczyk J (2014) Matrix metalloproteinase-9 involvement in the structural plasticity of dendritic spines. Front Neuroanat 8:68

5. Doble BW, Woodgett JR (2003) GSK-3: tricks of the trade for a multi-tasking kinase. J Cell Sci 116:1175-1186

6. Kremer A, Louis JV, Jaworski T, Van Leuven F (2011) GSK3 and Alzheimer's disease: facts and fiction. Front Mol Neurosci 4:17

7. Hoeflich KP, Luo J, Rubie EA, Tsao MS, Jin O, Woodgett JR (2000) Requirement for glycogen synthase kinase-3beta in cell survival and NF-kappaB activation. Nature 406:86-90

8. Kerkela R, Kockeritz L, Macaulay K, Zhou J, Doble BW, Beahm C, Greytak S, Woulfe K et al (2008) Deletion of GSK-3beta in mice leads to hypertrophic cardiomyopathy secondary to cardiomyoblast hyperproliferation. J Clin Invest 118:3609-3618

9. Jaworski T, Dewachter I, Lechat B, Gees M, Kremer A, Demedts D, Borghgraef P, Devijver H et al (2011) GSK-3 $\alpha / \beta$ kinases and amyloid production in vivo. Nature 480:E4-5

10. Kaidanovich-Beilin O, Lipina TV, Takao K, van Eede M, Hattori S, Laliberté C, Khan M, Okamoto K et al (2009) Abnormalities in brain structure and behavior in GSK-3alpha mutant mice. Mol Brain 2:35

11. Maurin H, Lechat B, Dewachter I, Ris L, Louis JV, Borghgraef P, Devijver H, Jaworski T et al (2013) Neurological characterization of mice deficient in GSK3 $\alpha$ highlight pleiotropic physiological functions in cognition and pathological activity as Tau kinase. Mol Brain 6:27

12. Hooper C, Markevich V, Plattner F, Killick R, Schofield E, Engel T, Hernandez F, Anderton B et al (2007) Glycogen synthase kinase-3 inhibition is integral to long-term potentiation. Eur J Neurosci 25: $81-86$

13. Biesemann C, Grønborg M, Luquet E, Wichert SP, Bernard V, Bungers SR, Cooper B, Varoqueaux F et al (2014) Proteomic screening of glutamatergic mouse brain synaptosomes isolated by fluorescence activated sorting. EMBO J 33:157-170

14. Peineau S, Taghibiglou C, Bradley C, Wong TP, Liu L, Lu J, Lo E, Wu D et al (2007) LTP inhibits LTD in the hippocampus via regulation of GSK3beta. Neuron 53:703-717

15. Dewachter I, Ris L, Jaworski T, Seymour CM, Kremer A, Borghgraef P, De Vijver H, Godaux E et al (2009) GSK3beta, a centre-staged kinase in neuropsychiatric disorders, modulates long term memory by inhibitory phosphorylation at serine- 9 . Neurobiol Dis 35:193-200

16. Jope RS, Roh MS (2006) Glycogen synthase kinase-3 (GSK3) in psychiatric diseases and therapeutic interventions. Curr Drug Targets 7:1421-1434 
17. Kaidanovich-Beilin O, Woodgett JR (2011) GSK-3: functional insights from cell biology and animal models. Front Mol Neurosci 4: 40

18. O’Brien WT, Huang J, Buccafusca R, Garskof J, Valvezan AJ, Berry GT, Klein PS (2011) Glycogen synthase kinase-3 is essential for $\beta$-arrestin- 2 complex formation and lithium-sensitive behaviors in mice. J Clin Invest 121:3756-3762

19. Gómez-Sintes R, Hernández F, Bortolozzi A, Artigas F, Avila J, Zaratin P, Gotteland JP, Lucas JJ (2007) Neuronal apoptosis and reversible motor deficit in dominant-negative GSK-3 conditional transgenic mice. EMBO J 26:2743-2754

20. Engel T, Hernández F, Avila J, Lucas JJ (2006) Full reversal of Alzheimer's disease-like phenotype in a mouse model with conditional overexpression of glycogen synthase kinase-3. J Neurosci 26: 5083-5090

21. Gould TD (2006) Targeting glycogen synthase kinase-3 as an approach to develop novel mood-stabilising medications. Expert Opin Ther Targets 10:377-392

22. Peineau S, Nicolas CS, Bortolotto ZA, Bhat RV, Ryves WJ, Harwood AJ, Dournaud P, Fitzjohn SM et al (2009) A systematic investigation of the protein kinases involved in NMDA receptordependent LTD: evidence for a role of GSK-3 but not other serine/ threonine kinases. Mol Brain 2:22

23. Nelson CD, Kim MJ, Hsin H, Chen Y, Sheng M (2013) Phosphorylation of threonine-19 of PSD-95 by GSK-3 $\beta$ is required for PSD-95 mobilization and long-term depression. J Neurosci 33: $12122-12135$

24. Chen P, Gu Z, Liu W, Yan Z (2007) Glycogen synthase kinase 3 regulates $\mathrm{N}$-methyl-D-aspartate receptor channel trafficking and function in cortical neurons. Mol Pharmacol 72:40-51

25. Wei J, Liu W, Yan Z (2010) Regulation of AMPA receptor trafficking and function by glycogen synthase kinase 3 . J Biol Chem 285: 26369-26376

26. Shahab L, Plattner F, Irvine EE, Cummings DM, Edwards FA (2014) Dynamic range of GSK $3 \alpha$ not GSK3 $\beta$ is essential for bidirectional synaptic plasticity at hippocampal CA3-CA1 synapses. Hippocampus 24:1413-1416

27. Ochs SM, Dorostkar MM, Aramuni G, Schön C, Filser S, Pöschl J, Kremer A, Van Leuven F et al (2015) Loss of neuronal GSK3 $\beta$ reduces dendritic spine stability and attenuates excitatory synaptic transmission via $\beta$-catenin. Mol Psychiatry 20:482-489

28. Llorens-Martín M, Fuster-Matanzo A, Teixeira CM, Jurado-Arjona J, Ulloa F, Defelipe J, Rábano A, Hernández F et al (2013) GSK-3 $\beta$ overexpression causes reversible alterations on postsynaptic densities and dendritic morphology of hippocampal granule neurons in vivo. Mol Psychiatry 18:451-460

29. Cymerman IA, Gozdz A, Urbanska M, Milek J, Dziembowska M, Jaworski J (2015) Structural plasticity of dendritic spines requires GSK $3 \alpha$ and GSK3 $\beta$. PLoS One 10:e0134018

30. Spittaels K, Van den Haute C, Van Dorpe J, Geerts H, Mercken M, Bruynseels K, Lasrado R, Vandezande K et al (2000) Glycogen synthase kinase-3beta phosphorylates protein tau and rescues the axonopathy in the central nervous system of human four-repeat tau transgenic mice. J Biol Chem 275:41340-41349

31. Spittaels K, Van den Haute C, Van Dorpe J, Terwel D, Vandezande K, Lasrado R, Bruynseels K, Irizarry M et al (2002) Neonatal neuronal overexpression of glycogen synthase kinase-3 beta reduces brain size in transgenic mice. Neuroscience 113:797-808

32. Wilczynski GM, Konopacki FA, Wilczek E, Lasiecka Z, Gorlewicz A, Michaluk P, Wawrzyniak M, Malinowska M et al (2008) Important role of matrix metalloproteinase 9 in epileptogenesis. J Cell Biol 180:1021-1035

33. Vu TH, Shipley JM, Bergers G, Berger JE, Helms JA, Hanahan D, Shapiro SD, Senior RM et al (1998) MMP-9/gelatinase B is a key regulator of growth plate angiogenesis and apoptosis of hypertrophic chondrocytes. Cell 93:411-422
34. Liu ZH, Chuang DM, Smith CB (2011) Lithium ameliorates phenotypic deficits in a mouse model of fragile $\mathrm{X}$ syndrome. Int $\mathrm{J}$ Neuropsychopharmacol 14:618-630

35. Michaluk P, Wawrzyniak M, Alot P, Szczot M, Wyrembek P, Mercik K, Medvedev N, Wilczek E et al (2011) Influence of matrix metalloproteinase MMP-9 on dendritic spine morphology. J Cell Sci 124:3369-3380

36. Ruszczycki B, Szepesi Z, Wilczynski GM, Bijata M, Kalita K, Kaczmarek L, Wlodarczyk J (2012) Sampling issues in quantitative analysis of dendritic spines morphology. BMC Bioinformatics 13: 213

37. Jasińska M, Miłek J, Cymerman IA, Łęski S, Kaczmarek L, Dziembowska M (2015) miR-132 Regulates dendritic spine structure by direct targeting of matrix metalloproteinase 9 mRNA. Mol Neurobiol; e-pub ahead of print 29 August 2015; doi:10.1007/ s12035-015-9383-z.

38. Te O (2007) Python for scientific computing. Comput Sci Eng 9: $10-20$

39. Pérez FGB (2007) IPython: a system for interactive scientific computing. Comput Sci Eng 9:21-29

40. Hunter JD (2007) Matplotlib: a 2D graphics environment. Comput Sci Eng 9:90-95

41. Michaluk P, Kolodziej L, Mioduszewska B, Wilczynski GM, Dzwonek J, Jaworski J, Gorecki DC, Ottersen OP et al (2007) Beta-dystroglycan as a target for MMP-9, in response to enhanced neuronal activity. J Biol Chem 282:16036-16041

42. Szklarczyk A, Lapinska J, Rylski M, McKay RD, Kaczmarek L (2002) Matrix metalloproteinase-9 undergoes expression and activation during dendritic remodeling in adult hippocampus. J Neurosci 22:920-930

43. R Core Team (2015) R: A language and environment for statistical computing. R Foundation for Statistical Computing 2015; http:// www.R-project.org

44. Bates D, Maechler M, Bolker BM, Walker S (2015) Fitting linear mixed-effects models using lme4. J Stat Softw 67:1-48. doi:10. 18637/jss.v067.i01

45. Szepesi Z, Bijata M, Ruszczycki B, Kaczmarek L, Wlodarczyk J (2013) Matrix metalloproteinases regulate the formation of dendritic spine head protrusions during chemically induced long-term potentiation. PLoS One 8:e63314

46. Wang XB, Bozdagi O, Nikitczuk JS, Zhai ZW, Zhou Q, Huntley GW (2008) Extracellular proteolysis by matrix metalloproteinase-9 drives dendritic spine enlargement and long-term potentiation coordinately. Proc Natl Acad Sci U S A 105:19520-19525

47. Gould TD, Chen G, Manji HK (2004) In vivo evidence in the brain for lithium inhibition of glycogen synthase kinase-3. Neuropsychopharmacology 29:32-38

48. O'Brien WT, Harper AD, Jové F, Woodgett JR, Maretto S, Piccolo S, Klein PS (2004) Glycogen synthase kinase-3beta haploinsufficiency mimics the behavioral and molecular effects of lithium. J Neurosci 24:6791-6798

49. Noble W, Planel E, Zehr C, Olm V, Meyerson J, Suleman F, Gaynor $\mathrm{K}$, Wang L et al (2005) Inhibition of glycogen synthase kinase-3 by lithium correlates with reduced tauopathy and degeneration in vivo. Proc Natl Acad Sci U S A 102:6990-6995

50. De Sarno P, Li X, Jope RS (2002) Regulation of Akt and glycogen synthase kinase-3 beta phosphorylation by sodium valproate and lithium. Neuropharmacology 43:1158-1164

51. Gould TD, Einat H, Bhat R, Manji HK (2004) AR-A014418, a selective GSK-3 inhibitor, produces antidepressant-like effects in the forced swim test. Int J Neuropsychopharmacol 7:387-390

52. Kaidanovich-Beilin O, Milman A, Weizman A, Pick CG, EldarFinkelman H (2004) Rapid antidepressive-like activity of specific glycogen synthase kinase-3 inhibitor and its effect on beta-catenin in mouse hippocampus. Biol Psychiatry 55:781-784 
53. Beaulieu JM, Marion S, Rodriguiz RM, Medvedev IO, Sotnikova TD, Ghisi V, Wetsel WC, Lefkowitz RJ et al (2008) A beta-arrestin 2 signaling complex mediates lithium action on behavior. Cell 132: 125-136

54. Beaulieu JM, Sotnikova TD, Yao WD, Kockeritz L, Woodgett JR, Gainetdinov RR, Caron MG (2004) Lithium antagonizes dopamine-dependent behaviors mediated by an AKT/glycogen synthase kinase 3 signaling cascade. Proc Natl Acad Sci U S A 101:5099-5104

55. Kondratiuk I, Devijver H, Lechat B, Van Leuven F, Kaczmarek L, Filipkowski RK (2013) Glycogen synthase kinase-3beta affects size of dentate gyrus and species-typical behavioral tasks in transgenic and knockout mice. Behav Brain Res 248:46-50

56. Nakashiba T, Young JZ, McHugh TJ, Buhl DL, Tonegawa S (2008) Transgenic inhibition of synaptic transmission reveals role of CA3 output in hippocampal learning. Science 319:1260-1264

57. Huntley GW (2012) Synaptic circuit remodelling by matrix metalloproteinases in health and disease. Nat Rev Neurosci 13:743-757

58. Kaczmarek L (2013) Mmp-9 inhibitors in the brain: can old bullets shoot new targets? Curr Pharm Des 19:1085-1089

59. Conant K, Allen M, Lim ST (2015) Activity dependent CAM cleavage and neurotransmission. Front Cell Neurosci 9:305

60. Mantuano E, Inoue G, Li X, Takahashi K, Gaultier A, Gonias SL, Campana WM (2008) The hemopexin domain of matrix metalloproteinase-9 activates cell signaling and promotes migration of schwann cells by binding to low-density lipoprotein receptorrelated protein. J Neurosci 28:11571-11582

61. Alessi DR, Andjelkovic M, Caudwell B, Cron P, Morrice N, Cohen $\mathrm{P}$, Hemmings BA (1996) Mechanism of activation of protein kinase B by insulin and IGF-1. EMBO J 15:6541-6551

62. Peng J, Awad A, Sar S, Hamze Komaiha O, Moyano R, Rayal A, Samuel D, Shewan A et al (2015) Phosphoinositide 3-kinase p $110 \delta$ promotes lumen formation through the enhancement of apico-basal polarity and basal membrane organization. Nat Commun 6:5937

63. van der Kooij MA, Fantin M, Rejmak E, Grosse J, Zanoletti O, Fournier C, Ganguly K, Kalita K et al (2014) Role for MMP-9 in stress-induced downregulation of nectin-3 in hippocampal CA1 and associated behavioural alterations. Nat Commun 5:4995

64. Ganguly K, Rejmak E, Mikosz M, Nikolaev E, Knapska E, Kaczmarek L (2013) Matrix metalloproteinase (MMP) 9 transcription in mouse brain induced by fear learning. J Biol Chem 288: 20978-20991

65. Nagy V, Bozdagi O, Matynia A, Balcerzyk M, Okulski P, Dzwonek J, Costa RM, Silva AJ et al (2006) Matrix metalloproteinase-9 is required for hippocampal late-phase long-term potentiation and memory. J Neurosci 26:1923-1934

66. Dziembowska M, Milek J, Janusz A, Rejmak E, Romanowska E, Gorkiewicz T, Tiron A, Bramham CR et al (2012) Activitydependent local translation of matrix metalloproteinase-9. J Neurosci 32:14538-14547

67. Shin S, Wolgamott L, Yu Y, Blenis J, Yoon SO (2011) Glycogen synthase kinase (GSK)-3 promotes $\mathrm{p} 70$ ribosomal protein S6 kinase (p70S6K) activity and cell proliferation. Proc Natl Acad Sci U S A 108:E1204-E1213

68. Inoki K, Ouyang H, Zhu T, Lindvall C, Wang Y, Zhang X, Yang Q, Bennett C et al (2006) TSC2 integrates Wnt and energy signals via a coordinated phosphorylation by AMPK and GSK3 to regulate cell growth. Cell 126:955-968

69. Shin S, Wolgamott L, Tcherkezian J, Vallabhapurapu S, Yu Y, Roux PP, Yoon SO (2014) Glycogen synthase kinase- $3 \beta$ positively regulates protein synthesis and cell proliferation through the regulation of translation initiation factor 4E-binding protein 1. Oncogene 33: 1690-1699

70. Yuste R, Bonhoeffer T (2001) Morphological changes in dendritic spines associated with long-term synaptic plasticity. Annu Rev Neurosci 24:1071-1089

71. He CX, Portera-Cailliau C (2013) The trouble with spines in fragile $\mathrm{X}$ syndrome: density, maturity and plasticity. Neuroscience 251 : $120-128$

72. Fiala JC, Spacek J, Harris KM (2002) Dendritic spine pathology: cause or consequence of neurological disorders? Brain Res Brain Res Rev 39:29-54

73. Bilousova TV, Dansie L, Ngo M, Aye J, Charles JR, Ethell DW, Ethell IM (2009) Minocycline promotes dendritic spine maturation and improves behavioural performance in the fragile X mouse model. J Med Genet 46:94-102

74. Mines MA, Yuskaitis CJ, King MK, Beurel E, Jope RS (2010) GSK3 influences social preference and anxiety-related behaviors during social interaction in a mouse model of fragile $\mathrm{X}$ syndrome and autism. PLoS One 5:e9706

75. Del'Guidice T, Latapy C, Rampino A, Khlghatyan J, Lemasson M, Gelao B, Quarto T, Rizzo G et al (2015) FXR1P is a GSK3 $\beta$ substrate regulating mood and emotion processing. Proc Natl Acad Sci U S A 112:E4610-E4619

76. Janusz A, Milek J, Perycz M, Pacini L, Bagni C, Kaczmarek L, Dziembowska M (2013) The Fragile X mental retardation protein regulates matrix metalloproteinase $9 \mathrm{mRNA}$ at synapses. J Neurosci $33: 18234-18241$ 